\title{
Symposium review: Modulating adipose tissue lipolysis and remodeling to improve immune function during the transition period and early lactation of dairy cows ${ }^{1}$
}

\author{
G. Andres Contreras, ${ }^{2}$ Clarissa Strieder-Barboza, and Jenne De Koster \\ Department of Large Animal Clinical Sciences, Michigan State University, East Lansing 48824
}

\begin{abstract}
Despite major advances in our understanding of transition and early lactation cow physiology and the use of advanced dietary, medical, and management tools, at least half of early lactation cows are reported to develop disease and over half of cow deaths occur during the first week of lactation. Excessive lipolysis, usually measured as plasma concentrations of free fatty acids (FFA), is a major risk factor for the development of displaced abomasum, ketosis, fatty liver, and metritis, and may also lead to poor lactation performance. Lipolysis triggers adipose tissue (AT) remodeling that is characterized by enhanced humoral and cell-mediated inflammatory responses and changes in its distribution of cellular populations and extracellular matrix composition. Uncontrolled AT inflammation could perpetuate lipolysis, as we have observed in cows with displaced abomasum, especially in those animals with genetic predisposition for excessive lipolysis responses. Efficient transition cow management ensures a moderate rate of lipolysis that is rapidly reduced as lactation progresses. Limiting FFA release from AT benefits immune function as several FFA are known to promote dysregulation of inflammation. Adequate formulation of pre- and postpartum diet reduces the intensity of AT lipolysis. Additionally, supplementation with niacin, monensin, and rumen-protected methyl donors (choline and methionine) during the transition period is reported to minimize FFA release into systemic circulation. Targeted supplementation of energy sources during early lactation improves energy balance and increases insulin concentration, which limits AT lipolytic responses. This review elaborates on the mechanisms by which uncontrolled lipolysis triggers inflammatory disorders.
\end{abstract}

\footnotetext{
Received June 15, 2017.

Accepted August 27, 2017.

${ }^{1}$ Presented as part of the Joint ADSA/National Mastitis Council Symposium: Mastitis Control and Milk Quality Globally: Past, Present, and an Amazing Future at the ADSA Annual Meeting, Pittsburgh, Pennsylvania, June 2017.

${ }^{2}$ Corresponding author: contre28@msu.edu
}

Details on current nutritional and pharmacological interventions that aid the modulation of FFA release from AT and their effect on immune function are provided. Understanding the inherent characteristics of AT biology in transition and early lactation cows will reduce disease incidence and improve lactation performance.

Key words: adipose tissue remodeling, free fatty acids, immune responses, lipolysis

\section{INTRODUCTION}

Adipose tissue (AT) is the energy storage organ in mammals. To fulfill this function, adipocytes store and release free fatty acids (FFA) as triacylglycerols (TAG). This process is described as lipid mobilization and includes lipolysis and lipogenesis (Figure 1). Starting around $3 \mathrm{wk}$ before parturition and up to 4 to $5 \mathrm{wk}$ postpartum, the rate of lipolysis surpasses that of lipogenesis, which is driven by hormonal changes associated with parturition and the onset of lactation and also by energy deficits resulting from high milk production and limited DMI (Bradford et al., 2015). As lactation progresses, lipolysis rate is reduced and lipogenesis replenishes TAG stores within the lipid droplet of adipocytes. The acute lipolytic activity around parturition and the onset of lactation leads to AT remodeling, a process characterized by an inflammatory response, enhanced immune cell trafficking, cellular proliferation, and extracellular matrix changes (Contreras et al., 2015). Although lipolysis ensures an adequate supply of energy around parturition, when intense and protracted, it predisposes cows to inflammatory and metabolic diseases by limiting AT capacity for energy buffering and contributing to chronically increased plasma FFA (Contreras and Sordillo, 2011; Bradford et al., 2015). In this review, we provide an overview of AT lipolysis and remodeling during the transition period and early lactation and its effects on AT and systemic inflammatory responses, and describe current dietary and pharmacological tools that can modulate AT lipolysis and how this may affect immune response during the transition period and early lactation. 


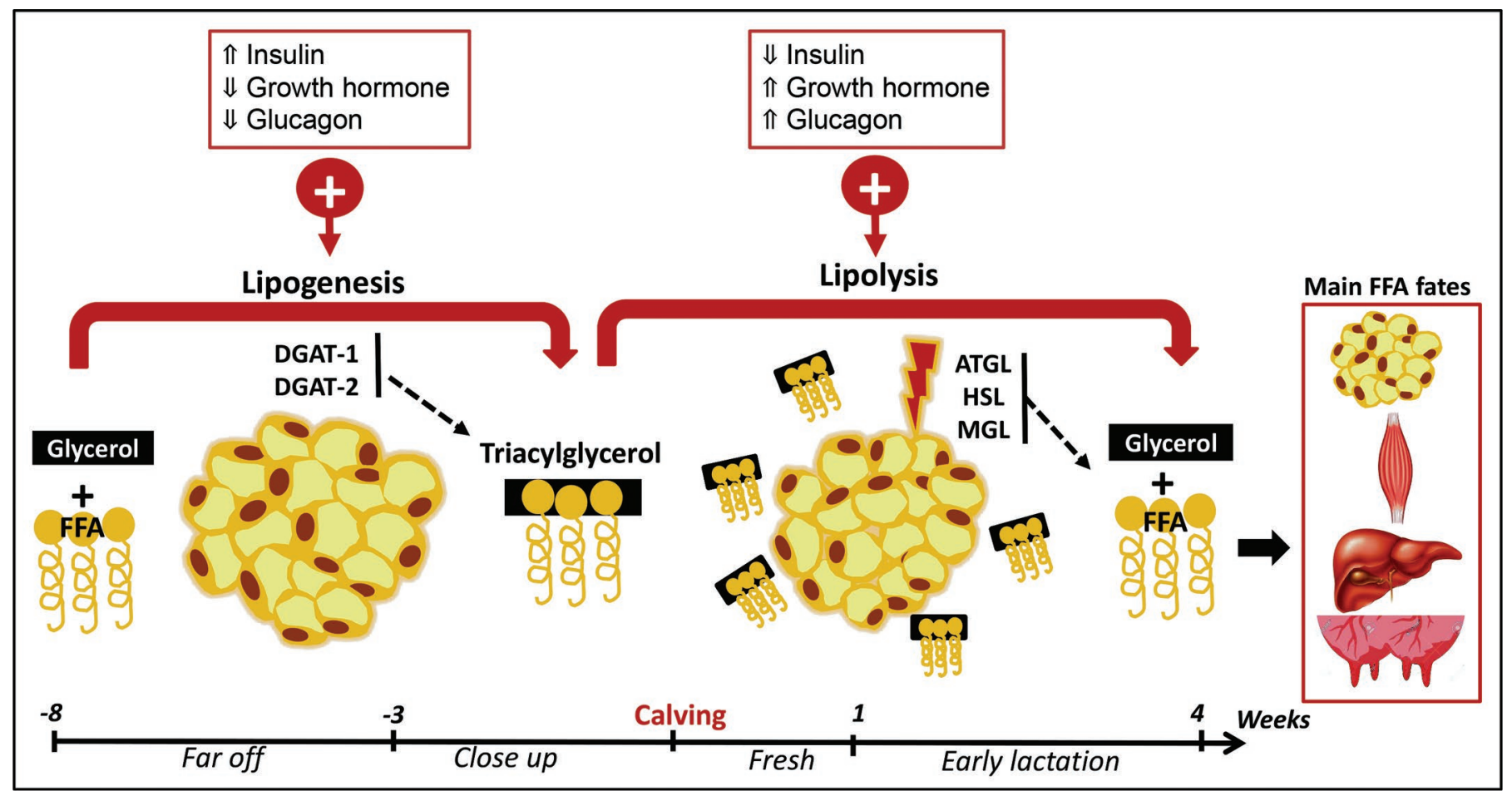

Figure 1. Lipid mobilization in transition dairy cows includes lipogenesis and lipolysis. Lipogenesis generates triacylglycerol from glycerol and free fatty acids (FFA) and is increased during the end of lactation and early dry period. In contrast, lipolysis is favored during the transition period and it releases FFA into circulation to be used by hepatocytes, myocytes, and mammary gland epithelial cells. Some FFA are also re-esterified in the adipocyte. Lipid mobilization is modulated by the action of insulin, glucagon, and growth hormone. ATGL = adipose triacylglyceride lipase; DGAT = diacylglycerol acyltransferase; HSL = hormone-sensitive lipase; MGL = monoacylglycerol lipase. Color version available online.

\section{LIPID STORAGE AND MOBILIZATION IN ADIPOSE TISSUES}

Lipogenesis and lipolysis are continuous processes occurring simultaneously within adipocytes. The relative balance between these processes determines whether there is net accumulation or net mobilization of TAG (Vernon, 2002). At the end of lactation and during the dry period, AT is storing energy as TAG in adipocytes (increased lipogenesis and decreased lipolysis, Figure $1)$, which are released during the negative energy balance (NEB) in early lactation (increased lipolysis and decreased lipogenesis, Figure 1; Vernon and Pond, 1997; Roche et al., 2009). In early lactation, endocrine signals (e.g., high growth hormone and glucagon, low insulin) favor the lipolytic pathway, whereas, at the end of lactation, different factors (e.g., high insulin, low growth hormone and glucagon) favor the lipogenic pathway (Ingvartsen, 2006).

During lipogenesis in the cytoplasm of adipocytes, 3 molecules of FFA are esterified with 1 molecule of glycerol, resulting in the formation of 1 TAG molecule. Initially, glycerol-3-phosphate is esterified by glycerol3 -phosphate acyl transferase (GPAT). The end product of this reaction is lysophosphatidic acid. An additional fatty acid is attached to this molecule by 1-acyl-glycerol-3-phosphate acyl transferase to yield phosphatidate. This phosphatidate can be converted to diacyglycerol by phosphatidate phosphatase-1. Diacylglycerol is converted into TAG by the activity of diacylglycerol acyltransferase (DGAT; Takeuchi and Reue, 2009). The FFA for TAG synthesis are either synthesized de novo or taken up from the bloodstream. De novo synthesis of FFA is regulated by the activity of 2 enzymes: acetyl CoA carboxylase (ACC) and fatty acid synthetase (FAS). For the de novo synthesis of FFA, ruminants preferably use acetate as substrate. Uptake of circulating FFA occurs via endothelial lipoprotein lipase (LPL; Roche et al., 2009, Vernon, 2002).

Lipolysis is mediated by the consecutive action of 3 enzymes: adipose triglyceride lipase (ATGL), hormone sensitive lipase (HSL), and monoacylglycerol lipase (MGL). One molecule of TAG is broken down into 3 FFA molecules and 1 molecule of glycerol. FFA are released in the bloodstream or are re-esterified in the lipogenic pathway. The hydrolysis of TAG is initiated by ATGL; next, HSL hydrolyses diacylglycerol with the formation of monoacylglycerol, and finally, MGL 
produces the final FFA acid molecule and glycerol (Jaworski et al., 2007; Zechner et al., 2009).

Lipolysis is stimulated via $\beta$-adrenergic receptors that activate protein kinase A (PKA) by increasing the intracellular concentration of cAMP (Zechner et al., 2009). Catecholamines are the major hormones to stimulate lipolysis and reach the AT via circulation (adrenalin) or via sympathetic innervation (noradrenaline; Jaworski et al., 2007). Lipolysis is inhibited by insulin which activates phosphodiesterase 3B (PDE-3B) with subsequent degradation of cAMP and decreased activation of PKA (Lafontan and Langin, 2009). Protein kinase A phosphorylates different target molecules, of which HSL is the most important. Phosphorylation of HSL increases its lipolytic activity. An additional factor that is phosphorylated upon stimulation of $\beta$-adrenergic receptors is perilipin, a protein localized at the surface of the lipid droplet. Upon phosphorylation, perilipin is translocated from the lipid droplet, rendering the surface of the lipid droplet accessible to HSL (Jaworski et al., 2007). Another protein, comparative gene identification 58 (CGI-58), is bound to unphosphorylated perilipin and detaches when perilipin is phosphorylated. Unbound CGI-58 stimulates the activity of ATGL to hydrolyze TAG (Zechner et al., 2009)

During the transition period, compared with other stages of lactation, AT lipolytic responses are enhanced due to hormonal changes associated with parturition and the onset of lactation (reviewed by Contreras et al., 2017). A surge in the plasma concentrations of growth hormone (Houseknecht and Bauman, 1997), prolactin (Fortun-Lamothe et al., 1996), and angiopoietin-like 4 (Koltes and Spurlock, 2012) around parturition and during the first weeks of lactation enhances lipolysis rate in adipocytes by reducing insulin sensitivity, limiting FFA uptake, and increasing their response to catecholamines.

The intensity of the lipolytic response during the transition period is highly variable, even among highproducing cows (Weber et al., 2013; Zachut and Moallem, 2017). There is a strong genetic component in the balance between lipogenesis and lipolysis around parturition. For example, cows of high genetic merit have lower rates of lipogenesis during the first $5 \mathrm{wk}$ after calving compared with those of low genetic merit (Khan et al., 2013). This difference is explained by a lower transcription rate of lipogenic genes postpartum and is reflected in higher rates of lipolysis in highgenetic-merit cows (Khan et al., 2013). Also, Zachut and colleagues (2013) demonstrated that cows predisposed to intense lipolytic response during the transition period exhibit impaired insulin signaling in AT that was positively associated with BW loss. Remarkably, cows that exhibit high lipolysis rate that leads to in- tense periparturient BW loss show a repetitive pattern across several lactations (Zachut and Moallem, 2017), suggesting that this predisposition for intense lipolytic responses has a genetic basis, coinciding with previous studies by Friggens et al. (2007) and Gross and Bruckmaier (2015). These reports highlight the importance of breeding strategies in the selection of animals with predisposition to moderate lipolytic responses during the transition period.

\section{ADIPOSE TISSUE REMODELING}

Lipolysis induces a remodeling process within the AT that comprises an inflammatory response that leads to changes in immune cell trafficking, proliferation of certain cell types, and rearrangements of its extracellular matrix (Figure 2; Rutkowski et al., 2015; Contreras et al., 2017). Adipose tissue remodeling is well characterized in certain human diseases and in rodent models of obesity and metabolic syndrome (Martinez-Santibañez and Nien-Kai Lumeng, 2014; Rutkowski et al., 2015; Pope et al., 2016). Recently, separate groups characterized various aspects of AT remodeling at different stages of lactation in dairy cows; however, given the limited pool of research tools available to study certain aspects of AT remodeling (such as cell turnover) in large mammals, it is often necessary to extrapolate from studies in rodent models of disease with intense AT remodeling processes.

\section{AT Inflammatory Response}

Most studies that describe the AT inflammatory process associated with lipolysis in transition dairy cows focus on gene expression profiling. Adipose tissue transcription of pro-inflammatory cytokines such as TNFA (encoding tumor necrosis factor- $\alpha$ ), IL6 (encoding interleukin-6), CCL2 (encoding macrophage chemoattractant protein-1) is upregulated during the transition period and peaks when the surge in AT lipolysis, reflected in high plasma concentrations of FFA, is observed (Sadri et al., 2009; Schmitt et al., 2011; Mann et al., 2016a). In response to lipolysis induced by NEB in late-lactation cows, TNFA gene expression was upregulated; however, no changes were observed in the transcription of other pro-inflammatory cytokines, including IL6 and CCL2 (Contreras et al., 2016). In over-conditioned nonlactating, nongestating cows (i.e., animals with higher basal lipolysis rate; De Koster et al., 2016), the expression of $I L 1 B$ (encoding IL-1 $\beta$ ), $C C L 2$, and $I L 6$ and its receptor (IL6R) is upregulated, especially in visceral AT (Ji et al., 2014). Zachut (2015) characterized the AT proteome in transition cows with intense and moderate lipolysis rates at $17 \mathrm{~d}$ before and 
$4 \mathrm{~d}$ after parturition. Among the 586 proteins evaluated in that study, the AT content of the inflammatory peptide complement $\mathrm{C} 3$ was reduced at $4 \mathrm{~d}$ in both groups of cows. No content changes were reported for other inflammatory cytokines. To further characterize the inflammatory responses during AT remodeling, more proteomic studies are needed, especially in cows that are predisposed to high lipolytic responses.

The populations of immune cells in AT are diverse and include mononuclear cells-macrophages, mast cells, lymphocytes, dendritic cells, and natural killer cells - and polymorphonuclear cells, including neutrophils, eosinophils, and basophils (Mathis, 2013). Among immune cells, macrophages are the most predominant immune cell type in AT of cattle (Ampem et al., 2016). As in other tissues, AT macrophage phenotype is broadly classified in classic (M1) and alternative (M2) depending on their response to classical inflammatory stimuli (Martinez and Gordon, 2014). During lipolysis, there is evidence for increased trafficking of macrophages into AT of dairy cows. Using a model of induced NEB in late-lactation cows, we observed a higher number of macrophages in subcutaneous and visceral AT in cows with high lipolysis (Contreras et al., 2016). The number of infiltrating macrophages appears to increase during protracted and intense lipolysis, as observed in early-lactation dairy cows with displaced abomasum. In these cows, macrophages were observed in higher numbers compared with those in late lactation and were also localized in aggregates, described as crownlike structures, within both omental and subcutaneous AT (Contreras et al., 2015). Based on their gene expression profile, infiltrating macrophages in cows with displaced abomasum appear to be polarized toward the M1 phenotype. In contrast, AT macrophages in latelactation cows during NEB did not appear to have a polarization shift to any of the phenotypes (Contreras et al., 2015, 2016). Adipose tissue macrophage functions during lipolysis include the removal of lipolytic products that can be cytotoxic (Lee et al., 2013), chemotaxis of other immune cells and preadipocytes (Lee et al., 2013), and the development of the inflammatory response through the secretion of cytokines such as TNF $\alpha$, IL-1 $\beta$, and IL-6 (Wisse, 2004; Nishimura et al., 2009). Interestingly, excessive macrophage infiltration into AT enhances lipolysis, creating a vicious cycle that connects lipolysis, ATM infiltration, and inflammation (Gao et al., 2014; Figure 2).
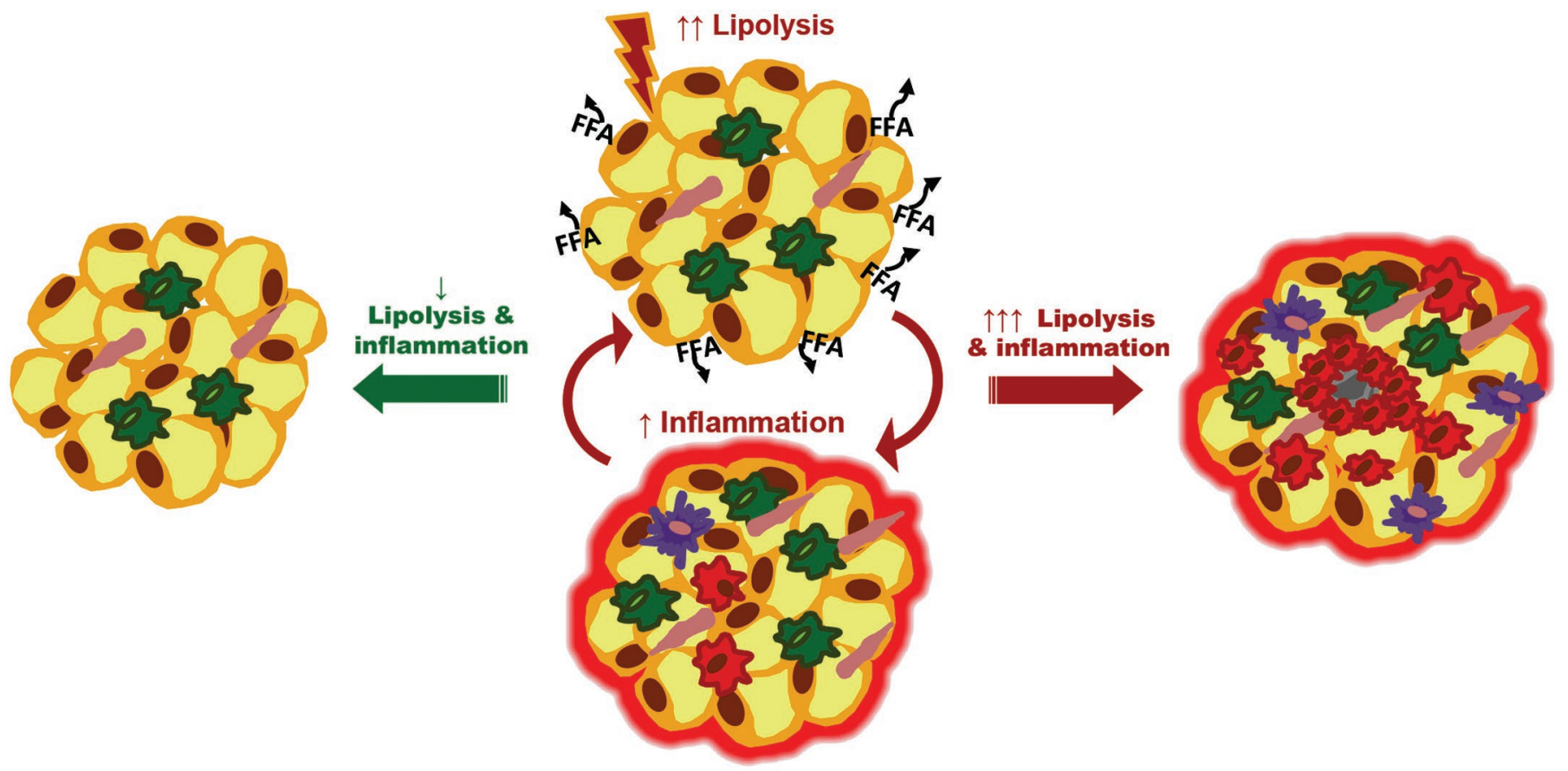

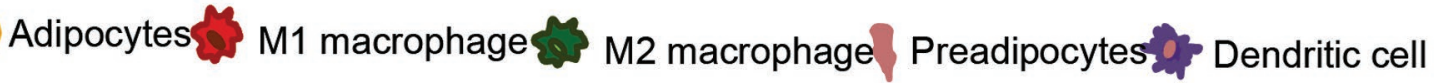

Figure 2. Lipolysis induces a remodeling process in adipose tissue (AT). As parturition approaches, lipolysis rate is moderately increased and macrophage infiltration occurs. In healthy transition cows with moderate lipolysis, macrophage infiltration is limited and involves mainly the M2 phenotype (anti-inflammatory). When lipolysis is excessive, most infiltrating macrophages are M1 (pro-inflammatory) and may further promote lipolysis by enhancing inflammation and reducing adipocyte insulin sensitivity. Excessive lipolysis and AT remodeling increase disease susceptibility and negatively affect lactation performance. FFA = free fatty acids. Color version available online. 
The trafficking dynamics of AT immune cells other than macrophages during the transition period and early lactation of dairy cows are unknown. Of the total population of non-buoyant cells (i.e., stromal vascular fraction) in AT of dairy cows, around 3 to $5 \%$ are $\mathrm{T}$ cells and 4 to $7 \%$ are B cells (Aylward et al., 2015; Contreras et al., 2015, 2016). The effect of changes in the distribution of lymphocytes populations in AT of dairy cows on metabolic function is unknown and warrants further investigation.

\section{Cell Proliferation}

Lipolysis promotes the proliferation of adipocyte progenitor cells in rodent models of obesity and adrenergic signaling (Lee et al., 2012). These new adipocytes replenish those fat cells that are lost due to apoptosis and pyroptosis and limit the lipotoxic effect driven by release of FFA into the adipose environment (Lee et al., 2014). Given the challenges of assessing cell turnover in large mammals such as dairy cows, separate groups have evaluated gene expression of cell cycle activation networks including CCNA2 (encoding cyclin A2), CCNB2 (encoding cyclin B2), and MKI67 (encoding Ki-67) or using immunohistochemistry to characterize the dynamics of progenitor cells. During the transition period in first-lactation cows, there is a 25 -fold increase in the number of preadipocytes, characterized as cells expressing the cell proliferation marker Ki-67 and progenitor cell marker Pref-1, in visceral AT compared with that in mid lactation (Häussler et al., 2013). However, in feed-restricted late-lactation cows, lipolysis did not increase the expression of CCNA2, CCNB2, or MKI67 (Contreras et al., 2016). Thus, cell proliferation in AT is triggered by the intensity and duration of the lipolytic stimuli.

\section{Extracellular Matrix}

In late-lactation dairy cows, extracellular matrix composition is affected by anatomical location, with higher expression of collagens I and VI in subcutaneous AT compared with omental AT (Contreras et al., 2016). Gene expression studies on the dynamics of extracellular matrix remodeling during the transition period and early lactation indicate that the expression of thrombospondin 1, an abundant glycoprotein in AT encoded by THBS1, is upregulated during peak lipolysis at the onset of lactation (Strieder-Barboza et al., 2017). Akbar et al. (2014) reported higher expression of collagen I in subcutaneous AT of transition cows with metritis compared with healthy animals. In goats, enhanced transcription of COL3A1 (encoding cyclin collagen $3 \mathrm{~A} 1$ ) was reported after a short-term feed-restriction protocol (Faulconnier et al., 2011). The proteomic analysis study by Zachut (2015) described dramatic changes in the concentrations of extracellular matrix in AT from cows with low and high lipolysis rates at $14 \mathrm{~d}$ before and $4 \mathrm{~d}$ after calving. The content of collagen $3 \mathrm{~A} 1$ was higher in cows with a high lipolysis rate compared with those with a low rate. Similarly, protein concentrations of collagen $6 \mathrm{~A} 2$ tended to be higher in the same group of cows. Interestingly, the protein content of tubulins including B, B1, B2, and B2B was increased in cows with high lipolysis rate. Zachut (2015) suggested a connection between the abundance of these structural proteins and impaired trafficking of GLUT4. Currently, the consequences of changes in the composition of extracellular matrix in dairy cows are unknown. In monogastric species, however, increased deposition of collagen 3,6 , and thrombospondin 1 reduced adipocyte sensitivity to insulin (Guglielmi et al., 2015).

\section{Adipokines}

Adipose tissue remodeling alters the secretion patterns of adipokines and, at the same time, is modulated by these bioactive compounds. Adipokines are secreted by adipocytes and other cellular components of AT, such as immune and vascular cells. Among adipokines, leptin and adiponectin are secreted exclusively by adipocytes. The secretion dynamics of these 2 major adipokines during periods of intense AT remodeling, such as the transition period in dairy cows, were characterized by different research groups. Adiponectin secretion is drastically reduced after calving, and then steadily increases to peak at around $60 \mathrm{~d}$ in milk (Giesy et al., 2012; Ohtani et al., 2012). Remarkably, circulating adiponectin content is inversely associated with plasma FFA (Kabara et al., 2014). Because adiponectin enhances lipogenesis in adipocytes and FFA $\beta$-oxidation in myocytes and hepatocytes (Stern et al., 2016), reduced concentrations of this adipokine during the transition period are speculated to improve glucose partitioning to the mammary gland (Giesy et al., 2012). Similar to adiponectin, AT secretion of leptin is rapidly reduced during the first week after calving, coinciding with a rapid increase in lipolysis rate (Block et al., 2001; Ehrhardt et al., 2016). Future studies are needed to evaluate the effects of extended periods of AT remodeling and lipolysis on the secretion patterns of adiponectin and leptin in dairy cows.

\section{LIPOLYSIS AND IMMUNE RESPONSES}

Several large epidemiological studies demonstrate that excessive lipolysis is associated with higher inci- 
dence and prevalence of disease in transition dairy cows (reviewed by Ospina et al., 2013). The mechanisms linking higher risk for periparturient disease and lipolysis are not completely understood, but several studies support a deleterious effect of high rates of lipolysis on both innate and adaptive immune responses.

\section{Innate Immunity}

Nonspecific defense mechanisms including physical barriers, phagocytes, vascular endothelium, and cellderived soluble factors act as the first line of defense against pathogens and are part of the innate immune system (Sordillo, 2016). Impaired function of phagocytes (i.e., polymorphonuclear and mononuclear cells) around parturition is one of the main reasons for increased susceptibility of transition cows to infectious diseases such as mastitis (Sander et al., 2011). As the rate of lipolysis increases, the efficacy of the inflammatory response of polymorphonuclear cells is challenged (Table 1). Moyes and colleagues (2009) demonstrated that cows experiencing high lipolysis rates after energy restriction and an intramammary challenge with Streptococcus uberis had increased number of immature polymorphonuclear cells in circulation with lower phagocytic capability compared with controls (Moyes et al., 2009). High lipolysis rates around parturition also appear to reduce polymorphonuclear chemotactic ability and impair their phagocytic capacity (Nonnecke et al., 2003; Hammon et al., 2006).

In support of these reports, Graugnard et al. (2012) observed that cows fed high-energy diets during the last 4 wk of the dry period had impaired phagocytic capacity of neutrophils before calving and then had higher NEB during early lactation. Even though changes in the phagocytic capacity of neutrophils may be partially explained by increased lipolysis rates, other factors such as the concentration of insulin and the availability of glucose (the preferred metabolic fuel for immune cells; Pithon-Curi et al., 2004) may also play an important role in modulating these cells' immune function. For example, Graugnard et al. (2012) suggested that in overfed cows, high prepartum insulin concentrations impaired neutrophil function by increasing their timing to adequately perform the phagocytosis process. Oxidative burst of polymorphonuclear cells is also inhibited when circulating FFA reach concentrations above 500 $\mu M$ (Ster et al., 2012). Additionally, polymorphonuclear cells exhibit decreased viability and increased necrosis when FFA concentrations are $>1 \mathrm{~m} M$ (Scalia et al., 2006). The adverse effects of high concentrations of plasma FFA on phagocytosis, oxidative burst, and viability of polymorphonuclear cells indicate that lipolysis causes immunosuppression by impairing the ability of phagocytes to clear pathogens. This is reflected in an increased risk for mastitis and uterine disorders in cows exhibiting high rates of lipolysis (Hammon et al., 2006; Moyes et al., 2009). Accordingly, Hammon et al. (2006) reported an association between decreased polymorphonuclear cell function and energy balance with uterine health disorders, even before parturition.

Mononuclear immune cell functionality is also affected by high rates of lipolysis. At high concentrations of FFA, mononuclear cell proliferation rate and mitogeninduced responses are reduced in transition cows (Ster et al., 2012). The effect of FFA on mononuclear cells appears to be dose dependent. At concentrations above $500 \mu M$ of a FFA mixture containing palmitic (30\%), palmitoleic $(5 \%)$, stearic $(15 \%)$, oleic $(45 \%)$, and linoleic (5\%) acids, mononuclear cell secretion of IFN- $\gamma$ was inhibited (Lacetera et al., 2004). The deleterious effects of high FFA concentrations on mononuclear cell function appear to be exacerbated in over-conditioned cows, which had lower IFN- $\gamma$ secretion compared with lean cows during the last week of gestation and first week of lactation and lower IgM secretion at 2 and 4

Table 1. Summary of effects of increased free fatty acid (FFA) concentrations on immune responses in periparturient dairy cows




wk after calving (Lacetera et al., 2005). Based on these results, the authors concluded that BCS, intensity of lipid mobilization, and circulating FFA concentrations are major factors altering lymphocyte functions in cows around calving. In fact, the authors observed a proportional effect between IgM and IFN- $\gamma$ secretions and the extent of BCS loss as assessed by measuring changes in BCS and circulating FFA. This is also supported by an earlier study where a deficiency of IFN- $\gamma$ secretion was observed in cows with fat mobilization syndrome (Szuster-Ciesielska et al., 1995). These studies highlight the multifactorial influences in the immune responses of periparturient cows; therefore, studies reporting a cause-effect relationship between excessive rates of lipolysis and impaired immunity should be carefully interpreted. Beyond intense lipolysis, other systemic adaptive or maladaptive changes associated with parturition and the onset of lactation have been associated with immunosuppression and dysfunctional innate immune responses, including neuroendocrine changes, milk production, genetic background, nutritional imbalances, and oxidative stress (Sordillo and Aitken, 2009; Ingvartsen and Moyes, 2015; Aleri et al., 2016). More research is needed to elucidate the role that complex interactions among adaptive lipolysis in AT and other physiological changes during the transition period play on innate immune function.

\section{Effect on Adaptive Response}

Very few studies demonstrate an effect of lipolysis intensity on adaptive immune responses of transition cows. Meglia et al. (2005) demonstrated that feeding dry cows high or very low energy diets to induce excessive lipolytic response in the transition period, affected the population's distribution of adaptive immune cells. In their study, Meglia et al. (2005) showed that cows with higher rates of lipolysis had an increased proportion of $\mathrm{B}$ lymphocytes and a reduction in the number of $\gamma \delta \mathrm{T}$ lymphocytes after. Because $\gamma \delta \mathrm{T}$ lymphocytes are cytoprotective by enhancing the T-helper $1 \mathrm{im}$ mune response in epithelial tissues (Pollock and Welsh, 2002), having limited cell numbers of this population might increase the susceptibility to infectious diseases in early lactation. The effect of an increased number of circulating B cells in cows with high rates of lipolysis is not clear because their immunoglobulin secretory response upon stimulation with mitogenic agents is reduced during the transition period (Nonnecke et al., 2003; Lacetera et al., 2004). Given the importance of optimal adaptive immunity in preventive herd health programs, it is necessary to expand our understanding of the direct effects of lipolysis intensity on adaptive immune responses.

\section{LIPOLYSIS MODULATION}

Transition dairy cows require a moderate level of lipolysis for a successful transitioning from pregnancy into lactation. Free fatty acids are an important energy source for non-mammary tissues and are used to produce milk fat (Figure 1). However, excessive lipolysis, characterized by high levels of FFA $(>0.3$ to 0.5 or $>0.7 \mathrm{mmol} / \mathrm{L}$, pre- or postpartum, respectively) and $\mathrm{BHB}(>1.0 \mathrm{mmol} / \mathrm{L}$, postpartum), is detrimental for health and productivity of dairy cows (Ospina et al., 2013; Van Saun and Sniffen, 2014). As pointed out in the review by Sordillo (2016), intense lipid mobilization modulates periparturient immune dysfunction, and one way to improve transition cow immunity is by decreasing lipolysis in the periparturient period.

Many physiological, nutritional, genetic, management, environmental, and pharmacological factors affect lipolysis and immune function, directly or indirectly, and involve complex cause-effect relationships. A good example is the systemic adaptation to heat stress that is known to affect lipolysis and immune function in the periparturient period of cows (Thompson et al., 2014; Faylon et al., 2015). However, high lipolysis as an isolated factor may not alter immune function. Perkins et al. (2002) reported that a period of nutrient restriction to induce FFA to levels as high as in the transition period did not affect immune function, demonstrating that other periparturient factors are necessary to induce immune dysfunction. It is beyond the scope of this review to discuss all factors and interventions that can modulate adipose lipolysis. In the next paragraphs, we focus on on-farm nutritional and pharmacological tools that are used routinely and have a direct effect on the metabolism of adipocytes. Field studies on limiting lipolysis and its effect on immunity are limited. Where possible, references are included to describe the simultaneous effect of the nutritional and pharmacological tools on adipose lipolysis and immune function.

\section{DMI}

A first objective in view of limiting adipose lipolysis is to maximize DMI both in the pre- and postpartum periods and to prevent a severe decrease in feed intake during the final weeks of the dry period (Bertics et al., 1992; Grummer et al., 2004). Prepartum DMI is an important determinant of postpartum DMI (Grummer et al., 2004); therefore, it is important to optimize transition cow management and housing (Cook and Nordlund, 2004). Maximizing postpartum DMI will improve energy balance, decrease the amount of adipose mobilization, and improve immune function (McCarthy et al., 2016). Additionally, it is hypothesized that basal 
circulating insulin concentrations might be positively related to DMI and nutritional status (Bradford and Allen, 2007; Rigolon et al., 2009) and may limit adipose lipolysis via increased activity of phosphodiesterase 3B with subsequent decreased activity of PKA and downstream lipolytic enzymes.

\section{Prepartum Energy}

In the past, the so-called steam-up feeding strategyfeeding a high-energy diet in the close-up period by increasing the level of NFC (by feeding more grain)was applied on many dairy herds. The rationale behind steam-up feeding was to prepare the rumen to digest higher amounts of grain in the immediate postpartum period and to alleviate the NEB at the end of the dry period (Friggens et al., 2004; Grummer, 2008). Additionally, the higher amounts of grain would stimulate the development of ruminal papillae to absorb more VFA. However, recent research indicated that despite the fact that papillae increased in size by feeding high amounts of grain in the prepartum period, this was not associated with a functional difference at the level of the absorption of VFA (Dieho et al., 2017). Furthermore, overfeeding energy in the dry period resulted in increased levels of FFA and liver lipid in the postpartum period and was associated with more postpartum health disorders (Dann et al., 2006; Douglas et al., 2006; Janovick et al., 2011). Although excessive insulin resistance could be a contributing factor in the excessive mobilization of AT in overfed cows (Holtenius et al., 2003), recent research demonstrates that AT insulin signaling is not attenuated in overfed cows (Ji et al., 2012; Mann et al., 2016a). Other factors that can be hypothesized to contribute in excessive lipolysis of cows overfed during the dry period are the greater amount of adipose mass, as overfed cows will accumulate excess energy in their adipose depots (Drackley et al., 2014), higher expression of ATGL (Ji et al., 2012), and an increase in adipocyte size. Larger adipocytes have higher levels of basal and stimulated lipolytic activity (De Koster et al., 2016). The current recommended strategy to feed cows during the dry period, in view of limiting lipolysis, is to meet but not exceed energy requirements while maximizing DMI. This is achieved by feeding high levels of fiber in the dry cow diet (Janovick et al., 2011; Allen and Piantoni, 2014; Van Saun and Sniffen, 2014).

\section{Postpartum Starch}

In the postpartum period, feeding diets with high amounts of starch has been shown to limit FFA mo- bilization (van Knegsel et al., 2007; McCarthy et al., 2015). Diets with elevated levels of starch will result in a high amount of propionate production in the rumen and increased glucose absorption in the intestines. Propionate and glucose stimulate the pancreas to release insulin and this will limit adipose lipolysis (McCarthy et al., 2015). It is important to note that starch levels have to be balanced with sufficient fiber, especially in the immediate postpartum period, to maintain rumen function (Allen and Piantoni, 2014; Lean et al., 2014). Higher starch levels without changes in fiber content led to improved immune function of monocytes and neutrophils (Yasui et al., 2016). However, high dietary starch may increase haptoglobin levels in the postpartum period reflecting enhanced systemic inflammatory responses (McCarthy et al., 2015). The origin of this inflammation could be the release of LPS from bacteria due to subclinical ruminal acidosis or a disruption of the gut barrier, known as the leaky gut (Bradford et al., 2015).

To optimize postpartum DMI, limiting the amount of highly fermentable starch sources is advisable. According to the hepatic oxidation theory, highly fermentable starch sources potentially increase the oxidation of energetic compounds in the liver, which increases the satiety signal in the brain and may limit DMI (Allen et al., 2009). Maximizing DMI is an important goal in fresh cows; therefore, moderately fermentable starch sources (e.g., dry ground corn) should be included in fresh cows diets (Allen and Piantoni, 2014).

\section{Niacin}

Niacin or vitamin $B_{3}$ plays a significant role in the cellular metabolism as part of the electron transporters NAD and NADP. The ruminal flora is able to synthesize niacin and ruminal production covers the daily requirements (NRC, 2001). However, when supplemented by abomasal infusion in feed-restricted cows, niacin has been shown to have strong antilipolytic effects (Pires et al., 2007). Niacin can be found in 2 forms: nicotinic acid (NA) and nicotinamide (NAM). In vitro research on bovine AT explants demonstrated that only NA has antilipolytic effects, by reducing the phosphorylation of hormone sensitive lipase (Kenéz et al., 2014). By binding to GPR109A, an inhibitory G protein coupled receptor, NA inhibits the activity of adenylate cyclase thereby decreasing the amount of cAMP, which reduces the activity of PKA and therefore limits the phosphorylation and activation of different proteins and enzymes in the lipolytic pathway (Karpe and Frayn, 2004).

The antilipolytic effect of NA is clearly demonstrated in a dose-dependent way in feed-restricted dairy cows 
by abomasal infusion of NA or administering rumenprotected NA (Pires et al., 2007; Pires and Grummer, 2007; Pescara et al., 2010). However, results from studies supplementing niacin in diets of dairy cows are inconsistent (NRC, 2001; Schwab et al., 2005; Niehoff et al., 2009). The reason for the large variability in niacin supplementation studies might the extensive ruminal breakdown of niacin (Schwab et al., 2005; Morey et al., 2011). In a recent study, Tienken et al. (2015) did not find any effect of supplementing rumen-unprotected niacin to transition dairy cows on lipolysis and immune parameters. In contrast, Morey et al. (2011) and Yuan et al. (2012) demonstrated FFA-lowering effects of niacin in transition dairy cows when feeding a commercially available rumen-protected form of niacin in the pre- and postpartum periods. Timing of the supplementation of rumen-protected niacin seems to be crucial in the FFA-lowering effect. In a large field trial, Havlin et al. (2017) did not demonstrate any FFA-lowering effect when feeding rumen-protected niacin. However, they only supplemented postpartum diets with niacin, whereas plasma FFA levels start to increase before calving and peak around calving; as such, supplemental niacin might be more effective when fed throughout the entire transition period (Schwab et al., 2005). Nevertheless, more research is needed to identify the optimal period of feeding rumen-protected niacin to transition dairy cows, to determine the effect on health and productivity of dairy cows, and to identify the dose that modulate lipolysis to prevent excessive FFA mobilization while maintaining sufficient FFA in the transition period to serve as alternative energy source (Karpe and Frayn, 2004; Grummer, 2008).

\section{Methyl Donors}

Nutritional interventions with methyl donors, such as choline and methionine, are reported to reduce liver TAG, enhance FFA oxidation capacity in hepatocytes, and improve lipid-exporting capacity of liver (see metaanalysis by Sales et al., 2010). In some studies, choline supplementation reduced lipolysis in AT (Cooke et al., 2007). Li et al. (2016) reported that methionine supplementation during the transition period (3 $\mathrm{wk}$ before through $3 \mathrm{wk}$ after calving) reduced plasma FFA at $10 \mathrm{~d}$ before calving in cows fed a high-energy diet but not in those fed a low-calorie diet. Recently, postruminal supplementation of both methionine and choline significantly reduced AT lipolysis compared with methionine or choline alone (Sun et al., 2016). The mechanisms behind this synergistic effect were identified in rodent models of nonalcoholic fatty liver disease that were fed diets deficient in choline and methionine for up to $10 \mathrm{wk}$ (Tanaka et al., 2014; Chen et al., 2016). In these mice models, choline and methionine deficiencies lead to hepatocyte TAG accumulation and, at the same time, enhance adipocyte lipolysis. Both choline and methionine are extensively degraded in the rumen by bacteria and therefore need to be fed in a rumenprotected form to ensure release and absorption in the small intestine (Deuchler et al., 1998). It is noteworthy that the effects of feeding methyl donors in excess have not been investigated in dairy cows. A classic experiment from the 1950s using the rat as a model showed that overfeeding methionine ( $4.8 \%$ of the diet) induces extensive lipolysis that leads to intense weight loss (Roth and Allison, 1950). In the same experiment, rats tolerated choline when included in levels up to $1.8 \%$ of the diet. More recently, Acar et al. (2001) found that feeding methionine at $1.86 \%$ of the diet led broilers to a drastic loss of abdominal fat. Laying hens tolerate choline and methionine when fed up to $1 \%$ over the dietary needs (Koelkebeck et al., 1991). It is unlikely that these levels of feeding of methyl donors could be reached in commercial herds but dietary inclusion limits should be acknowledged.

\section{Monensin}

Monensin is an ionophore used as a feed additive in the diets of dairy cows. Especially in transition dairy cows, its positive effects on health, productivity, and metabolism have been demonstrated by a series of meta-analyses by Duffield et al. (2008a,b,c). Generally, monensin decreases circulating FFA in the postpartum period. This effect is more pronounced if monensin is fed in both the pre- and postpartum periods compared with feeding during only the pre- or postpartum period (Duffield et al., 2008a). The effect of monensin on adipocyte lipolysis is most probably indirect. Because of the selective inhibition of gram-positive bacteria in the rumen of monensin-fed cows, propionic acid production of feed ingredients is favored, whereas the synthesis of butyric and acetic acid is reduced. The propionic acid is used by the liver in the tricarboxylic acid and gluconeogenic cycles, resulting in reduced levels of BHB and increased levels of glucose. Propionic acid and glucose are important insulin secretagogues that potentially limit FFA mobilization from adipocytes (Green et al., 1999; McCarthy et al., 2015). However, insulin levels were not significantly influenced by monensin in the meta-analysis by Duffield et al. (2008a). Immune function of monocytes and neutrophils was enhanced when monensin was fed throughout the periparturient period (Yasui et al., 2016). Those authors hypothesized that the positive effects of feeding monensin and high starch 
levels on immune cell function were due to the greater availability of glucose that is used for anaerobic glycolysis by the immune cells, which improves chemotaxis, phagocytosis, and killing activity.

\section{Chromium}

Chromium is an essential trace element and plays a role in the carbohydrate and lipid metabolism. Trivalent chromium $\left(\mathrm{Cr}^{3+}\right)$ binds to chromodulin (formerly known as low-molecular-weight chromium-binding protein) and potentiates the effect of insulin on insulinsensitive tissues. Although the exact mechanism is not yet fully elucidated, it has been demonstrated that a part of the effect is due to the Cr-chromodulin complex binding to the $\beta$-subunit of the insulin receptor after binding of insulin to the $\alpha$-subunit of the insulin receptor. After association, Cr-chromodulin stimulates the tyrosine kinase activity of the insulin receptor of the insulin activated insulin receptor (Vincent, 2000, 2004; Hua et al., 2012). By potentiating the downstream signaling of insulin, Cr-chromodulin stimulates glucose uptake and lipogenesis (Davis and Vincent, 1997).

Different forms of chromium have been used as feed supplement in transition cows in different trials: $\mathrm{Cr}-$ propionate, Cr-methionine and, Cr-picolinate. Supplementing $\mathrm{Cr}$ affects both metabolic and immune function in transition dairy cows; however, the effects are inconsistent. Although some studies have demonstrated lower prepartum or postpartum FFA levels when supplementing Cr prepartum (Hayirli et al., 2001; Soltan, 2010; Yasui et al., 2014), others failed to demonstrate an effect of $\mathrm{Cr}$ on FFA level of transition dairy cows (Williams et al., 2004; McNamara and Valdez, 2005; Smith et al., 2008). Differences might be explained by the use of different formulations of $\mathrm{Cr}$, the time when supplementation started, the applied dose of $\mathrm{Cr}$, and rumen fermentability of the starch source (Sadri et al., 2009; Rockwell and Allen, 2016).

By performing an in vitro explant study of adipose biopsies of transition dairy cows, McNamara and Valdez (2005) suggested that $\mathrm{Cr}$ might influence lipid metabolism by increasing lipogenesis without affecting lipolysis. Net result in transition dairy cows would be a reduced release of FFA from the AT (McNamara and Valdez, 2005).

\section{Glucogenic Precursors}

The glucogenic precursors, propylene glycol, glycerol, and propionate, have been frequently used and studied in the treatment and prevention of excessive lipid mobilization (Gordon et al., 2013; Piantoni and
Allen, 2015). Especially propylene glycol seems effective in inhibiting lipolysis (Piantoni and Allen, 2015). After an oral bolus of propylene glycol, insulin levels peak within $1 \mathrm{~h}$ followed by a temporary increase in glucose levels and a decrease in FFA and BHB (Nielsen and Ingvartsen, 2004). Glucogenic precursors stimulate insulin secretion in 2 ways. First, glucogenic precursors are fermented in the rumen to propionic acid which, when absorbed, is a strong stimulus for the pancreas to secrete insulin. Second, glucose levels increase due to conversion of the glucogenic precursors and propionic acid into glucose in the gluconeogenic pathway in the liver (Nielsen and Ingvartsen, 2004). The effect is limited in time because glucogenic precursors are quickly metabolized, and insulin and glucose return to baseline levels within $4 \mathrm{~h}$ (Piantoni and Allen, 2015).

Nevertheless, a protocol of testing fresh cows for excessive lipid mobilization (by assessing BHB) and treating ketotic cows with $300 \mathrm{~g}$ of propylene glycol for $5 \mathrm{~d}$ was successful in reducing the risk of different metabolic disorders and in increasing milk production (McArt et al., 2011, 2012; Ospina et al., 2013). A recent study determined that $3 \mathrm{~d}$ of treatment is effective in decreasing BHB concentration below the threshold of $1.2 \mathrm{mmol} / \mathrm{L}$ if BHB levels on the day of diagnosis are below $2.4 \mathrm{mmol} / \mathrm{L}$ (Gordon et al., 2017). From these studies, it seems that administering glucogenic precursors for 3 or $5 \mathrm{~d}$ limits adipose lipolysis sufficiently to support the cow to adapt her metabolism and cope with the high energetic demand for milk production. A crucial factor in the effect of glucogenic precursors is the route of administration. Only when administered as an oral bolus will propylene glycol affect lipid mobilization. When mixed into a TMR, the intake of propylene glycol is spread over the day and the beneficial bolus and peak effect disappears (Nielsen and Ingvartsen, 2004; Bjerre-Harpoth et al., 2015).

\section{Insulin}

Insulin has been proposed as a pharmacological agent to limit lipid mobilization due to its strong antilipolytic effects. However, its preventive and therapeutic effects have never been proven. When given without a concomitant glucose source, insulin has no effect on FFA level or it increases FFA levels (Hayirli et al., 2002; Winkelman and Overton, 2013). This is most probably due to the hypoglycemia associated with administering insulin (Hayirli et al., 2002; Winkelman and Overton, 2013). Hypoglycemia activates counterregulatory mechanisms, leading to an increase of FFA mobilization that counteracts the inhibitory effect of insulin on lipolysis (Bolli and Fanelli, 1999). This is especially the case for 
fresh cows that have naturally lower levels of glucose due to the glucose drain to the mammary gland and the depression in feed intake (De Koster and Opsomer, 2013). In a large field study, insulin did not improve ketosis cure when administered with propylene glycol as a glucose source (Gordon et al., 2017).

\section{Glucocorticoids}

Glucocorticoids have been proposed as therapeutic agents to treat cows suffering from excessive fat mobilization and ketosis in the postpartum period. Glucocorticoids affect the metabolism of transition dairy cows in diverse ways. Glucocorticoids seem to inhibit hepatic gluconeogenesis (Starke et al., 2009); as such, the transient hyperglycemia observed when administering glucocorticoids to cows is caused by a redistribution of glucose in the body away from the mammary gland with a decrease in milk production. Most of the recent studies did not observe a decrease in FFA when administering glucocorticoids to healthy (Kusenda et al., 2013; van der Drift et al., 2015) or diseased cows (Jorritsma et al., 2004; Seifi et al., 2007; Sami et al., 2015), whereas the effect of glucocorticoids in treating ketotic cows was dependent on initial BHB levels (Tatone et al., 2016). It can be concluded that glucocorticoids are not effective in limiting AT lipolysis in transition dairy cows.

\section{Glucose}

Intravenous administration of glucose or dextrose has frequently been used in the therapy of excessive lipid mobilization in postpartum dairy cows (Herdt and Emery, 1992). A bolus infusion of glucose increases blood glucose and insulin concentrations for a limited time (generally less than $3 \mathrm{~h}$ ). The increase in glucose and insulin limits AT lipolysis and reduces FFA levels for a short period (Schoenberg et al., 2012; Mann et al., 2016b). The effect is limited in time; therefore, animals should be followed up with other supportive treatments (Gordon et al., 2013). In a recent study, a combination therapy of glucose with glucogenic precursors was metabolically beneficial compared with no treatment or glucose or glucogenic precursors only in early-lactation hyperketonemic dairy cows (Mann et al., 2017). There have been concerns regarding the fact that a large part of the infused glucose is excreted via the kidneys. However, Grūnberg et al. (2006) determined that less than $5 \%$ of the infused glucose was lost in the urine in high-yielding dairy cows. Although a bolus infusion of glucose is the most practical way of administering glucose to dairy cows in the field, some studies provide evidence for a FFA-lowering effect of continuous glucose infusions in healthy cows (Al-Trad et al., 2009; Lucy et al., 2013). However, more research is needed to identify the efficacy and economic effects of glucose infusions in the treatment of excessive lipid mobilization in transition dairy cows (Gordon et al., 2013).

\section{CONCLUSIONS}

Elevated rates of lipolysis during the transition period may lead to an acute AT remodeling process that could impair AT capacity for buffering excessive concentrations of circulating FFA and therefore increase the risk for metabolic and inflammatory diseases. Intense research on adipose tissue biology in monogastrics during the past 2 decades, driven by the epidemic of obesity and metabolic syndrome in humans, has shown the important role that the AT plays on modulating lipid metabolism and systemic inflammation in these chronic diseases (Caputo et al., 2017). However, the unique metabolic challenges that the AT of dairy cows is subjected to during the transition period limits the scope of extrapolating results from research in rodent models of AT biology and humans. Currently, there is a gap in our knowledge of the changes that occur in the AT of dairy cows during extended periods of intense lipolysis, including the dynamics of AT cellular and extracellular matrix responses, the changes in adipokine secretion beyond leptin and adiponectin, and the role that AT inflammation plays in the development of low grade systemic inflammation that has been described by other authors. Advancing our understanding of AT biology in the transition period will improve cow health and lactation performance.

\section{ACKNOWLEDGMENTS}

This work supported in part by the Agriculture and Food Research Initiative Competitive Grants Programs of the USDA National Institute for Food and Agriculture (Washington, DC; projects 2014-68004-21972 and 2015-67015-23207), MSU Department of Large Animal Clinical Sciences (East Lansing), the MSU Elwood Kirkpatrick Dairy Science Research Endowment (East Lansing), and the Michigan Alliance for Animal Agriculture (East Lansing).

\section{REFERENCES}

Acar, N., G. F. Barbato, and P. H. Patterson. 2001. 2. The effect of feeding excess methionine on live performance, carcass traits, and ascitic mortality. Poult. Sci. 80:1585-1589.

Akbar, H., F. C. Cardoso, S. Meier, C. Burke, S. McDougall, M. Mitchell, C. Walker, S. L. Rodriguez-Zas, R. E. Everts, H. A. 
Lewin, J. R. Roche, and J. J. Loor. 2014. Postpartal subclinical endometritis alters transcriptome profiles in liver and adipose tissue of dairy cows. Bioinform. Biol. Insights 8:45-63.

Al-Trad, B., K. Reisberg, T. Wittek, G. B. Penner, A. Alkaassem, G. Gäbel, M. Fürll, and J. R. Aschenbach. 2009. Increasing intravenous infusions of glucose improve body condition but not lactation performance in mid-lactation dairy cows. J. Dairy Sci. 92:5645-5658.

Aleri, J. W., B. C. Hine, M. F. Pyman, P. D. Mansell, W. J. Wales, B. Mallard, and A. D. Fisher. 2016. Periparturient immunosuppression and strategies to improve dairy cow health during the periparturient period. Res. Vet. Sci. 108:8-17.

Allen, M. S., B. J. Bradford, and M. Oba. 2009. Board-Invited Review: The hepatic oxidation theory of the control of feed intake and its application to ruminants. J. Anim. Sci. 87:3317-3334.

Allen, M. S., and P. Piantoni. 2014. Carbohydrate nutrition: Managing energy intake and partitioning through lactation. Vet. Clin. North Am. Food Anim. Pract. 30:577-597.

Ampem, G., H. Azegrouz, Á. Bacsadi, L. Balogh, S. Schmidt, J. Thuróczy, and T. Röszer. 2016. Adipose tissue macrophages in non-rodent mammals: A comparative study. Cell Tissue Res. 363:461-478.

Aylward, B. A. A., M. Clark, A. Barnard, W. Jen, C. Gittens, T. Gressley, E. Brannick, M. Fecteau, and D. Dyer. 2015. Immune cells populate mesenteric adipose tissues of Holstein Friesian cows. J. Dairy Sci. 98:292.

Bertics, S. J., R. R. Grummer, C. Cadorniga-Valino, and E. E. Stoddard. 1992. Effect of prepartum dry matter intake on liver triglyceride concentration and early lactation. J. Dairy Sci. 75:1914-1922.

Bjerre-Harpoth, V., A. C. Storm, M. Eslamizad, B. Kuhla, and M. Larsen. 2015. Effect of propylene glycol on adipose tissue mobilization in postpartum over-conditioned Holstein cows. J. Dairy Sci. 98:8581-8596.

Block, S. S., W. Butler, R. Ehrhardt, A. Bell, M. Amburgh, and Y. Boisclair. 2001. Decreased concentration of plasma leptin in periparturient dairy cows is caused by negative energy balance. J. Endocrinol. 171:339-348.

Bolli, G. B., and C. G. Fanelli. 1999. Physiology of glucose counterregulation to hypoglycemia. Endocrinol. Metab. Clin. North Am. 28:467-493.

Bradford, B. J., and M. S. Allen. 2007. Depression in feed intake by a highly fermentable diet is related to plasma insulin concentration and insulin response to glucose infusion. J. Dairy Sci. 90:38383845 .

Bradford, B. J., K. Yuan, J. K. Farney, L. K. Mamedova, and A. J. Carpenter. 2015. Invited review: Inflammation during the transition to lactation: New adventures with an old flame. J. Dairy Sci. 98:6631-6650.

Būhler, S., J. Frahm, R. Tienken, S. Kersten, U. Meyer, K. Huber, and S. Danicke. 2016. Influence of energy level and nicotinic acid supplementation on apoptosis of blood leukocytes of periparturient dairy cows. Vet. Immunol. Immunopathol. 179:36-45.

Caputo, T., F. Gilardi, and B. Desvergne. 2017. From chronic overnutrition to metaflammation and insulin resistance: Adipose tissue and liver contributions. FEBS Lett.https://doi.org/10.1002/1873 -3468.12742 .

Chen, R., Q. Wang, S. Song, F. Liu, B. He, and X. Gao. 2016. Protective role of autophagy in methionine-choline deficient diet-induced advanced nonalcoholic steatohepatitis in mice. Eur. J. Pharmacol. 770:126-133.

Contreras, G. A., E. Kabara, J. Brester, L. Neuder, and M. Kiupel. 2015. Macrophage infiltration in the omental and subcutaneous adipose tissues of dairy cows with displaced abomasum. J. Dairy Sci. 98:6176-6187.

Contreras, G. A., and L. M. Sordillo. 2011. Lipid mobilization and inflammatory responses during the transition period of dairy cows. Comp. Immunol. Microbiol. Infect. Dis. 34:281-289.

Contreras, G. A., C. Strieder-Barboza, and W. Raphael. 2017. Adipose tissue lipolysis and remodeling during the transition period of dairy cows. J. Anim. Sci. Biotechnol. 8:41.
Contreras, G. A., K. Thelen, S. Schmidt, C. Strieder-Barboza, C. Preseault, R. Raphael, M. Kiupel, J. Caron, and A. Lock. 2016. Adipose tissue remodeling in late-lactation dairy cows during feed restriction-induced negative energy balance. J. Dairy Sci. 99:10009-10021.

Cook, N. B., and K. V. Nordlund. 2004. Behavioral needs of the transition cow and considerations for special needs facility design. Vet. Clin. North Am. Food Anim. Pract. 20:495-520.

Cooke, R. F., N. S. Del Río, D. Z. Caraviello, S. J. Bertics, M. H Ramos, and R. R. Grummer. 2007. Supplemental choline for prevention and alleviation of fatty liver in dairy cattle. J. Dairy Sci. 90:2413-2418.

Dann, H. M., N. B. Litherland, J. P. Underwood, M. Bionaz, A. D'Angelo, J. W. McFadden, and J. K. Drackley. 2006. Diets during far-off and close-up dry periods affect periparturient metabolism and lactation in multiparous cows. J. Dairy Sci. 89:3563-3577.

Davis, C. M., and J. B. Vincent. 1997. Chromium in carbohydrate and lipid metabolism. J. Biol. Inorg. Chem. 2:675-679.

De Koster, J., W. Van Den Broeck, L. Hulpio, E. Claeys, M. Van Eetvelde, K. Hermans, M. Hostens, V. Fievez, and G. Opsomer. 2016. Influence of adipocyte size and adipose depot on the in vitro lipolytic activity and insulin sensitivity of adipose tissue in dairy cows at the end of the dry period. J. Dairy Sci. 99:2319-2328.

De Koster, J. D., and G. Opsomer. 2013. Insulin resistance in dairy cows. Vet. Clin. North Am. Food Anim. Pract. 29:299-322.

Deuchler, K. N., L. S. Piperova, and R. A. Erdman. 1998. Milk choline secretion as an indirect indicator of postruminal choline supply. J. Dairy Sci. 81:238-242.

Dieho, K., J. Dijkstra, G. Klop, J. T. Schonewille, and A. Bannink. 2017. The effect of supplemental concentrate fed during the dry period on morphological and functional aspects of rumen adaptation in dairy cattle during the dry period and early lactation. J. Dairy Sci. 100:343-356.

Douglas, G. N., T. R. Overton, H. G. Bateman, H. M. Dann, and J. K. Drackley. 2006. Prepartal plane of nutrition, regardless of dietary energy source, affects periparturient metabolism and dry matter intake in Holstein cows. J. Dairy Sci. 89:2141-2157.

Drackley, J. K., R. L. Wallace, D. Graugnard, J. Vasquez, B. F. Richards, and J. J. Loor. 2014. Visceral adipose tissue mass in nonlactating dairy cows fed diets differing in energy density. J. Dairy Sci. 97:3420-3430.

Duffield, T. F., A. R. Rabiee, and I. J. Lean. 2008a. A meta-analysis of the impact of monensin in lactating dairy cattle. Part 1. Metabolic effects. J. Dairy Sci. 91:1334-1346.

Duffield, T. F., A. R. Rabiee, and I. J. Lean. 2008b. A meta-analysis of the impact of monensin in lactating dairy cattle. Part 2. Production effects. J. Dairy Sci. 91:1347-1360.

Duffield, T. F., A. R. Rabiee, and I. J. Lean. 2008c. A meta-analysis of the impact of monensin in lactating dairy cattle. Part 3. Health and reproduction. J. Dairy Sci. 91:2328-2341.

Ehrhardt, R. A., A. Foskolos, S. L. Giesy, S. R. Wesolowski, C. S. Krumm, and W. R. Butler. 2016. Increased plasma leptin attenuates adaptive metabolism in early lactating dairy cows. J. Endocrinol. 229:145-157.

Faulconnier, Y., Y. Chilliard, M. B. M. Torbati, and C. Leroux. 2011. The transcriptomic profiles of adipose tissues are modified by feed deprivation in lactating goats. Comp. Biochem. Physiol. Part D Genomics Proteomics 6:139-149.

Faylon, M. P., L. H. Baumgard, R. P. Rhoads, and D. M. Spurlock. 2015. Effects of acute heat stress on lipid metabolism of bovine primary adipocytes. J. Dairy Sci. 98:8732-8740.

Fortun-Lamothe, L., D. Langin, and M. Lafontan. 1996. Influence of prolactin on in vivo and in vitro lipolysis in rabbits. Comp. Biochem. Physiol. C Pharmacol. Toxicol. Endocrinol. 115:141-147.

Friggens, N. C., J. B. Andersen, T. Larsen, O. Aaes, and R. J. Dewhurst. 2004. Priming the dairy cow for lactation: A review of dry cow feeding strategies. Anim. Res. 53:453-473.

Friggens, N. C., P. Berg, P. Theilgaard, I. R. Korsgaard, K. L. Ingvartsen, P. Løvendahl, and J. Jensen. 2007. Breed and parity effects on energy balance profiles through lactation: Evidence of genetically driven body energy change. J. Dairy Sci. 90:5291-5305. 
Gao, D., M. Madi, C. Ding, M. Fok, T. Steele, C. Ford, L. Hunter, and C. Bing. 2014. Interleukin-1beta mediates macrophage-induced impairment of insulin signaling in human primary adipocytes. Am. J. Physiol. Endocrinol. Metab. 307:E289-304.

Giesy, S. L., B. Yoon, W. B. Currie, J. W. Kim, and Y. R. Boisclair. 2012. Adiponectin deficit during the precarious glucose economy of early lactation in dairy cows. Endocrinology 153:5834-5844.

Gordon, J. L., T. Duffield, T. Herdt, D. Kelton, L. Neuder, and S. LeBlanc. 2017. Effects of a combination butaphosphan and cyanocobalamin product and insulin on ketosis resolution and milk production. J. Dairy Sci. 100:2954-2966.

Gordon, J. L., S. J. LeBlanc, and T. F. Duffield. 2013. Ketosis treatment in lactating dairy cattle. Vet. Clin. North Am. Food Anim. Pract. 29:433-445.

Graugnard, D. E., M. Bionaz, E. Trevisi, K. M. Moyes, J. L. SalakJohnson, R. L. Wallace, J. K. Drackley, G. Bertoni, and J. J. Loor. 2012. Blood immunometabolic indices and polymorphonuclear neutrophil function in peripartum dairy cows are altered by level of dietary energy prepartum. J. Dairy Sci. 95:1749-1758.

Green, B. L., B. W. McBride, D. Sandals, K. E. Leslie, R. Bagg, and P. Dick. 1999. The impact of a monensin controlled-release capsule on subclinical ketosis in the transition dairy cow. J. Dairy Sci. 82:333-342.

Gross, J. J., and R. M. Bruckmaier. 2015. Repeatability of metabolic responses to a nutrient deficiency in early and mid lactation and implications for robustness of dairy cows. J. Dairy Sci. 98:86348643.

Grummer, R. R. 2008. Nutritional and management strategies for the prevention of fatty liver in dairy cattle. Vet. J. 176:10-20.

Grummer, R. R., D. G. Mashek, and A. Hayirli. 2004. Dry matter intake and energy balance in the transition period. Vet. Clin. North Am. Food Anim. Pract. 20:447-470.

Grūnberg, W., D. E. Morin, J. K. Drackley, and P. D. Constable. 2006. Effect of rapid intravenous administration of $50 \%$ dextrose solution on phosphorus homeostasis in postparturient dairy cows. J. Vet. Intern. Med. 20:1471-1478.

Guglielmi, V., M. Cardellini, F. Cinti, F. Corgosinho, I. Cardolini, M. D'Adamo, M. C. Zingaretti, A. Bellia, D. Lauro, P. Gentileschi, M. Federici, S. Cinti, and P. Sbraccia. 2015. Omental adipose tissue fibrosis and insulin resistance in severe obesity. Nutr. Diabetes 5:e175.

Hammon, D. S., I. M. Evjen, T. R. Dhiman, J. P. Goff, and J. L. Walters. 2006. Neutrophil function and energy status in Holstein cows with uterine health disorders. Vet. Immunol. Immunopathol. 113:21-29.

Häussler, S., D. Germeroth, K. Friedauer, S. H. Akter, S. Dänicke, and H. Sauerwein. 2013. Characterization of the dynamics of fat cell turnover in different bovine adipose tissue depots. Res. Vet. Sci. 95:1142-1150.

Havlin, J., P. Robinson, and J. Garrett. 2017. Niacin feeding to fresh dairy cows: Immediate effects on health and milk production. Anim. Prod. Sci. 57:1069-1078.

Hayirli, A., S. J. Bertics, and R. R. Grummer. 2002. Effects of slowrelease insulin on production, liver triglyceride, and metabolic profiles of Holsteins in early lactation. J. Dairy Sci. 85:2180-2191.

Hayirli, A., D. R. Bremmer, S. J. Bertics, M. T. Socha, and R. R. Grummer. 2001. Effect of chromium supplementation on production and metabolic parameters in periparturient dairy cows. J. Dairy Sci. 84:1218-1230.

Herdt, T. H., and R. S. Emery. 1992. Therapy of diseases of ruminant intermediary metabolism. Vet. Clin. North Am. Food Anim. Pract. 8:91-106.

Hoeben, D., E. Monfardini, G. Opsomer, C. Burvenich, H. Dosogne, A. De Kruif, and J. F. Beckers. 2000. Chemiluminescence of bovine polymorphonuclear leucocytes during the periparturient period and relation with metabolic markers and bovine pregnancyassociated glycoprotein. J. Dairy Res. 67:249-259.

Holtenius, K., S. Agenas, C. Delavaud, and Y. Chilliard. 2003. Effects of feeding intensity during the dry period. 2. Metabolic and hormonal responses. J. Dairy Sci. 86:883-891.
Houseknecht, K. L., and D. E. Bauman. 1997. Regulation of lipolysis by somatotropin: Functional alteration of adrenergic and adenosine signaling in bovine adipose tissue. J. Endocrinol. 152:465-475.

Hua, Y., S. Clark, J. Ren, and N. Sreejayan. 2012. Molecular mechanisms of chromium in alleviating insulin resistance. J. Nutr. Biochem. 23:313-319.

Ingvartsen, K. L. 2006. Feeding- and management-related diseases in the transition cow-Physiological adaptations around calving and strategies to reduce feeding-related diseases. Anim. Feed Sci. Technol. 126:175-213.

Ingvartsen, K. L., and K. M. Moyes. 2015. Factors contributing to immunosuppression in the dairy cow during the periparturient period. Jpn. J. Vet. Res. 63(Suppl. 1):S15-S24.

Janovick, N. A., Y. R. Boisclair, and J. K. Drackley. 2011. Prepartum dietary energy intake affects metabolism and health during the periparturient period in primiparous and multiparous Holstein cows. J. Dairy Sci. 94:1385-1400.

Jaworski, K., E. Sarkadi-Nagy, R. E. Duncan, M. Ahmadian, and H. S. Sul. 2007. Regulation of triglyceride metabolism. IV. Hormonal regulation of lipolysis in adipose tissue. Am. J. Physiol. Gastrointest. Liver Physiol. 293:G1-G4.

Ji, P., J. K. Drackley, M. J. Khan, and J. J. Loor. 2014. Inflammationand lipid metabolism-related gene network expression in visceral and subcutaneous adipose depots of Holstein cows. J. Dairy Sci. 97:3441-3448

Ji, P., J. S. Osorio, J. K. Drackley, and J. J. Loor. 2012. Overfeeding a moderate energy diet prepartum does not impair bovine subcutaneous adipose tissue insulin signal transduction and induces marked changes in peripartal gene network expression. J. Dairy Sci. 95:4333-4351.

Jorritsma, R., J. Thanasak, M. Holweling, J. P. T. M. Noordhuizen, and K. E. Muller. 2004. Effects of a single dose of dexamethasone21-isonicotinate on the metabolism of heifers in early lactation. Vet. Rec. 155:521-523.

Kabara, E., L. M. Sordillo, S. Holcombe, and G. A. Contreras. 2014. Adiponectin links adipose tissue function and monocyte inflammatory responses during bovine metabolic stress. Comp. Immunol. Microbiol. Infect. Dis. 37:49-58.

Karpe, F., and K. N. Frayn. 2004. The nicotinic acid receptor-A new mechanism for an old drug. Lancet 363:1892-1894.

Kenéz, A., L. Locher, J. Rehage, S. Danicke, and K. Huber. 2014. Agonists of the $\mathrm{G}$ protein-coupled receptor 109A-mediated pathway promote antilipolysis by reducing serine residue 563 phosphorylation of hormone-sensitive lipase in bovine adipose tissue explants. J. Dairy Sci. 97:3626-3634.

Khan, M. J., A. Hosseini, S. Burrell, S. M. Rocco, J. P. McNamara, and J. J. Loor. 2013. Change in subcutaneous adipose tissue metabolism and gene network expression during the transition period in dairy cows, including differences due to sire genetic merit. J. Dairy Sci. 96:2171-2182.

Koelkebeck, K. W., D. H. Baker, Y. Han, and C. M. Parsons. 1991. Research note: Effect of excess lysine, methionine, threonine, or tryptophan on production performance of laying hens. Poult. Sci. 70:1651-1653.

Koltes, D. A., and D. M. Spurlock. 2012. Adipose tissue angiopoietinlike protein 4 messenger RNA changes with altered energy balance in lactating Holstein cows. Domest. Anim. Endocrinol. 43:307-316.

Kusenda, M., M. Kaske, M. Piechotta, L. Locher, A. Starke, K. Huber, and J. Rehage. 2013. Effects of dexamethasone-21-isonicotinate on peripheral insulin action in dairy cows 5 days after surgical correction of abomasal displacement. J. Vet. Intern. Med. 27:200-206.

Lacetera, N., D. Scalia, U. Bernabucci, B. Ronchi, D. Pirazzi, and A. Nardone. 2005. Lymphocyte functions in overconditioned cows around parturition. J. Dairy Sci. 88:2010-2016.

Lacetera, N., D. Scalia, O. Franci, U. Bernabucci, B. Ronchi, and A. Nardone. 2004. Short communication: Effects of nonesterified fatty acids on lymphocyte function in dairy heifers. J. Dairy Sci. $87: 1012-1014$.

Lafontan, M., and D. Langin. 2009. Lipolysis and lipid mobilization in human adipose tissue. Prog. Lipid Res. 48:275-297. 
Lean, I. J., H. M. Golder, and M. B. Hall. 2014. Feeding, evaluating, and controlling rumen function. Vet. Clin. North Am. Food Anim. Pract. 30:539-575.

Lee, Y.-H., E. P. Mottillo, and J. G. Granneman. 2014. Adipose tissue plasticity from WAT to BAT and in between. Biochim. Biophys. Acta 1842:358-369.

Lee, Y.-H., A. Petkova, and J. Granneman. 2013. Identification of an adipogenic niche for adipose tissue remodeling and restoration. Cell Metab. 18:355-367.

Lee, Y.-H., A. Petkova, E. Mottillo, and J. Granneman. 2012. In vivo identification of bipotential adipocyte progenitors recruited by $\beta 3$ adrenoceptor activation and high-fat feeding. Cell Metab. 15:480491.

Li, C., F. Batistel, J. S. Osorio, J. K. Drackley, D. Luchini, and J. J. Loor. 2016. Peripartal rumen-protected methionine supplementation to higher energy diets elicits positive effects on blood neutrophil gene networks, performance and liver lipid content in dairy cows. J. Anim. Sci. Biotechnol. 7:18.

Lucy, M. C., R. C. Escalante, D. H. Keisler, W. R. Lamberson, and D. J. Mathew. 2013. Short communication: Glucose infusion into early postpartum cows defines an upper physiological set point for blood glucose and causes rapid and reversible changes in blood hormones and metabolites. J. Dairy Sci. 96:5762-5768.

Mann, S., D. V. Nydam, A. Abuelo, F. A. Leal Yepes, T. R. Overton, and J. J. Wakshlag. 2016a. Insulin signaling, inflammation, and lipolysis in subcutaneous adipose tissue of transition dairy cows either overfed energy during the prepartum period or fed a controlled-energy diet. J. Dairy Sci. 99:6737-6752.

Mann, S., F. A. L. Yepes, M. Duplessis, J. J. Wakshlag, T. R. Overton, B. P. Cummings, and D. V. Nydam. 2016b. Dry period plane of energy: Effects on glucose tolerance in transition dairy cows. J. Dairy Sci. 99:701-717.

Mann, S., F. L. Yepes, E. Behling-Kelly, and J. McArt. 2017. The effect of different treatments for early-lactation hyperketonemia on blood $\beta$-hydroxybutyrate, plasma nonesterified fatty acids, glucose, insulin, and glucagon in dairy cattle. J. Dairy Sci.100:64706482. https://doi.org/10.3168/jds.2016-12532.

Martinez, F. O., and S. Gordon. 2014. The M1 and M2 paradigm of macrophage activation: Time for reassessment. F1000Prime Rep. $6: 13$.

Martinez-Santibañez, G., and C. Nien-Kai Lumeng. 2014. Macrophages and the regulation of adipose tissue remodeling. Annu. Rev. Nutr. 34:57-76.

Mathis, D. 2013. Immunological goings-on in visceral adipose tissue. Cell Metab. 17:851-859.

McArt, J. A. A., D. V. Nydam, and G. R. Oetzel. 2012. A field trial on the effect of propylene glycol on displaced abomasum, removal from herd, and reproduction in fresh cows diagnosed with subclinical ketosis. J. Dairy Sci. 95:2505-2512

McArt, J. A. A., D. V. Nydam, P. A. Ospina, and G. R. Oetzel. 2011. A field trial on the effect of propylene glycol on milk yield and resolution of ketosis in fresh cows diagnosed with subclinical ketosis. J. Dairy Sci. 94:6011-6020.

McCarthy, M. M., T. Yasui, M. J. B. Felippe, and T. R. Overton. 2016. Associations between the degree of early lactation inflammation and performance, metabolism, and immune function in dairy cows. J. Dairy Sci. 99:680-700.

McCarthy, M. M., T. Yasui, C. M. Ryan, S. H. Pelton, G. D. Mechor, and T. R. Overton. 2015. Metabolism of early-lactation dairy cows as affected by dietary starch and monensin supplementation. J. Dairy Sci. 98:3351-3365.

McNamara, J. P., and F. Valdez. 2005. Adipose tissue metabolism and production responses to calcium propionate and chromium propionate. J. Dairy Sci. 88:2498-2507.

Meglia, G. E., A. Johannisson, S. Agenäs, K. Holtenius, and K. P. Waller. 2005. Effects of feeding intensity during the dry period on leukocyte and lymphocyte sub-populations, neutrophil function and health in periparturient dairy cows. Vet. J. 169:376-384.

Morey, S. D., L. K. Mamedova, D. E. Anderson, C. K. Armendariz, E. C. Titgemeyer, and B. J. Bradford. 2011. Effects of encapsulated niacin on metabolism and production of periparturient dairy cows. J. Dairy Sci. 94:5090-5104.

Moyes, K. M., J. K. Drackley, J. L. Salak-Johnson, D. E. Morin, J. C. Hope, and J. J. Loor. 2009. Dietary-induced negative energy balance has minimal effects on innate immunity during a Streptococcus uberis mastitis challenge in dairy cows during mid lactation. J. Dairy Sci. 92:4301-4316.

Niehoff, I. D., L. Huther, and P. Lebzien. 2009. Niacin for dairy cattle: A review. Br. J. Nutr. 101:5-19.

Nielsen, N. I., and K. L. Ingvartsen. 2004. Propylene glycol for dairy cows: A review of the metabolism of propylene glycol and its effects on physiological parameters, feed intake, milk production and risk of ketosis. Anim. Feed Sci. Technol. 115:191-213.

Nishimura, S., I. Manabe, M. Nagasaki, K. Eto, H. Yamashita, M Ohsugi, M. Otsu, K. Hara, K. Ueki, S. Sugiura, K. Yoshimura, T. Kadowaki, and R. Nagai. 2009. CD8+ effector T cells contribute to macrophage recruitment and adipose tissue inflammation in obesity. Nat. Med. 15:914-920.

Nonnecke, B. J., K. Kimura, J. P. Goff, and M. E. Kehrli Jr.. 2003. Effects of the mammary gland on functional capacities of blood mononuclear leukocyte populations from periparturient cows. J. Dairy Sci. 86:2359-2368.

NRC. 2001. Nutrient Requirements of Dairy Cattle. Vol. 1. 7th ed. National Academies Press, Washington, DC.

Ohtani, Y., T. Takahashi, K. Sato, A. Ardiyanti, S.-H. Song, and R. Sato. 2012. Changes in circulating adiponectin and metabolic hormone concentrations during periparturient and lactation periods in Holstein dairy cows. Anim. Sci. J. 83:788-795.

Ospina, P. A., J. McArt, T. Overton, T. Stokol, and D. Nydam. 2013 Using nonesterified fatty acids and $\beta$-hydroxybutyrate concentrations during the transition period for herd-level monitoring of increased risk of disease and decreased reproductive and milking performance. Vet. Clin. North Am. Food Anim. Pract. 29:387-412.

Perkins, K. H., M. J. VandeHaar, J. L. Burton, J. S. Liesman, R. J. Erskine, and T. H. Elsasser. 2002. Clinical responses to intramammary endotoxin infusion in dairy cows subjected to feed restriction. J. Dairy Sci. 85:1724-1731.

Pescara, J. B., J. A. A. Pires, and R. R. Grummer. 2010. Antilipolytic and lipolytic effects of administering free or ruminally protected nicotinic acid to feed-restricted Holstein cows. J. Dairy Sci 93:5385-5396

Petzold, M., U. Meyer, S. Kersten, J. Spilke, G. Breves, and S. Dänicke. 2015. Impacts of CLA and dietary concentrate proportion on blood metabolite concentration and proliferation of peripheral blood mononuclear cells of periparturient dairy cows. Animal 9:481-489.

Piantoni, P., and M. S. Allen. 2015. Evaluation of propylene glycol and glycerol infusions as treatments for ketosis in dairy cows. J. Dairy Sci. 98:5429-5439.

Pires, J. A. A., and R. R. Grummer. 2007. The use of nicotinic acid to induce sustained low plasma nonesterified fatty acids in feedrestricted Holstein cows. J. Dairy Sci. 90:3725-3732.

Pires, J. A., J. B. Pescara, and R. R. Grummer. 2007. Reduction of plasma NEFA concentration by nicotinic acid enhances the response to insulin in feed-restricted Holstein cows. J. Dairy Sci. 90:4635-4642

Pithon-Curi, T. C., M. P. De Melo, and R. Curi. 2004. Glucose and glutamine utilization by rat lymphocytes, monocytes and neutrophils in culture: A comparative study. Cell Biochem. Funct. $22: 321-326$

Pollock, J. M., and M. D. Welsh. 2002. The WC1 $+\gamma \delta$ T-cell population in cattle: A possible role in resistance to intracellular infection. Vet. Immunol. Immunopathol. 89:105-114.

Pope, B. D., C. R. Warren, K. K. Parker, and C. A. Cowan. 2016. Microenvironmental control of adipocyte fate and function. Trends Cell Biol.26:745-755. https://doi.org/10.1016/j.tcb.2016.05.005. PubMed

Rigolon, L. P., I. N. do Prado, F. L. B. Cavalieri, W. G. do Nascimento, L. C. Copovila, F. D. Ramos, and F. B. Moreira. 2009 Effect of the dry matter intake level on the sanguine profile of glu- 
cose, insulin, urea, estrogen and progesterone and concentration of IGF-I in the follicular liquid of crossbred heifers. Braz. Arch. Biol. Technol. 52:61-68.

Roche, J. R., N. C. Friggens, J. K. Kay, M. W. Fisher, K. J. Stafford, and D. P. Berry. 2009. Invited review: Body condition score and its association with dairy cow productivity, health, and welfare. J. Dairy Sci. 92:5769-5801.

Rockwell, R. J., and M. S. Allen. 2016. Chromium propionate supplementation during the peripartum period interacts with starch source fed postpartum: Production responses during the immediate postpartum and carryover periods. J. Dairy Sci. 99:4453-4463.

Roth, J. S., and J. B. Allison. 1950. The effects of feeding excess DLmethionine and choline chloride to rats on a casein diet. J. Biol. Chem. 183:173-178.

Rutkowski, J. M., J. H. Stern, and P. E. Scherer. 2015. The cell biology of fat expansion. J. Cell Biol. 208:501-512.

Sadri, H., G. R. Ghorbani, H. R. Rahmani, A. H. Samie, M. Khorvash, and R. M. Bruckmaier. 2009. Chromium supplementation and substitution of barley grain with corn: Effects on performance and lactation in periparturient dairy cows. J. Dairy Sci. 92:5411-5418.

Sales, J., P. Homolka, and V. Koukolová. 2010. Effect of dietary rumen-protected choline on milk production of dairy cows: A metaanalysis. J. Dairy Sci. 93:3746-3754.

Sami, M., M. Mohri, and H. A. Seifi. 2015. Effects of dexamethasone and insulin alone or in combination on energy and protein metabolism indicators and milk production in dairy cows in early lactation-A randomized controlled trial. PLoS One 10:e0139276.

Sander, A. K., M. Piechotta, G. Schlamberger, H. Bollwein, M. Kaske, A. Sipka, and H. Schuberth. 2011. Ex vivo phagocytic overall performance of neutrophilic granulocytes and the relation to plasma insulin-like growth factor-I concentrations in dairy cows during the transition period. J. Dairy Sci. 94:1762-1771.

Scalia, D., N. Lacetera, U. Bernabucci, K. Demeyere, L. Duchateau, and C. Burvenich. 2006. In vitro Effects of nonesterified fatty acids on bovine neutrophils oxidative burst and viability. J. Dairy Sci. $89: 147-154$.

Schmitt, E., M. A. Ballou, M. N. Correa, E. J. DePeters, J. K. Drackley, and J. J. Loor. 2011. Dietary lipid during the transition period to manipulate subcutaneous adipose tissue peroxisome proliferator-activated receptor- $\gamma$ co-regulator and target gene expression. J. Dairy Sci. 94:5913-5925.

Schoenberg, K. M., R. M. Ehrhardt, and T. R. Overton. 2012. Effects of plane of nutrition and feed deprivation on insulin responses in dairy cattle during late gestation. J. Dairy Sci. 95:670-682.

Schwab, E., D. Caraviello, and R. Shaver. 2005. Review: A metaanalysis of lactation responses to supplemental dietary niacin in dairy cows. Prof. Anim. Sci. 21:239-247.

Seifi, H. A., S. J. LeBlanc, E. Vernooy, K. E. Leslie, and T. F. Duffield. 2007. Effect of isoflupredone acetate with or without insulin on energy metabolism, reproduction, milk production, and health in dairy cows in early lactation. J. Dairy Sci. 90:4181-4191.

Smith, K. L., M. R. Waldron, L. C. Ruzzi, J. K. Drackley, M. T. Socha, and T. R. Overton. 2008. Metabolism of dairy cows as affected by prepartum dietary carbohydrate source and supplementation with chromium throughout the periparturient period. J. Dairy Sci. 91:2011-2020.

Soltan, M. A. 2010. Effect of dietary chromium supplementation on productive and reproductive performance of early lactating dairy cows under heat stress. J. Anim. Physiol. Anim. Nutr. (Berl.) 94:264-272.

Sordillo, L. M. 2016. Nutritional strategies to optimize dairy cattle immunity. J. Dairy Sci. 99:4967-4982.

Sordillo, L. M., and S. L. Aitken. 2009. Impact of oxidative stress on the health and immune function of dairy cattle. Vet. Immunol. Immunopathol. 128:104-109.

Starke, A., K. Wussow, L. Matthies, M. Kusenda, R. Busche, A. Haudum, A. Beineke, and J. Rehage. 2009. Novel minimal invasive technique for measuring hepatic metabolism quantitatively in dairy cows exemplified by studying hepatic glucose-net production after dexamethasone treatment. Pages 664-666 in Ruminant Physiology: Digestion, Metabolism, and Effects of Nutrition on
Reproduction and Welfare. Wageningen Academic Publishers, Wageningen, the Netherlands.

Ster, C., M. C. Loiselle, and P. Lacasse. 2012. Effect of postcalving serum nonesterified fatty acids concentration on the functionality of bovine immune cells. J. Dairy Sci. 95:708-717.

Stern, J. H., J. Rutkowski, and P. Scherer. 2016. Adiponectin, leptin, and fatty acids in the maintenance of metabolic homeostasis through adipose tissue crosstalk. Cell Metab. 23:770-784.

Strieder-Barboza, C., J. de Souza, A. L. Lock, and G. A. Contreras. 2017. Effect of prepartum adiposity and lipolysis on gestational and postnatal adipose tissue inflammation and immune cell infiltration. FASEB J. 31:964.

Sun, F., Y. Cao, C. Cai, S. Li, C. Yu, and J. Yao. 2016. Regulation of nutritional metabolism in transition dairy cows: Energy homeostasis and health in response to post-ruminal choline and methionine. PLoS One 11:e0160659.

Szuster-Ciesielska, A., J. Filar, and M. Kandefer-Szerszeń. 1995. Depression of interferon production in leukocytes of cows with fat mobilization syndrome. Arch. Immunol. Ther. Exp. (Warsz.) 43:61-65.

Takeuchi, K., and K. Reue. 2009. Biochemistry, physiology, and genetics of GPAT, AGPAT, and lipin enzymes in triglyceride synthesis. Am. J. Physiol. Endocrinol. Metab. 296:E1195-E1209.

Tanaka, N., S. Takahashi, Z.-Z. Fang, T. Matsubara, K. W. Krausz, A. Qu, and F. J. Gonzalez. 2014. Role of white adipose lipolysis in the development of NASH induced by methionine- and cholinedeficient diet. Biochim. Biophys. Acta 1841:1596-1607.

Tatone, E. H., T. F. Duffield, M. B. Capel, T. J. DeVries, S. J. LeBlanc, and J. L. Gordon. 2016. A randomized controlled trial of dexamethasone as an adjunctive therapy to propylene glycol for treatment of hyperketonemia in postpartum dairy cattle. J. Dairy Sci. 99:8991-9000.

Thompson, I. M. T., S. Tao, A. P. A. Monteiro, K. C. Jeong, and G. E. Dahl. 2014. Effect of cooling during the dry period on immune response after Streptococcus uberis intramammary infection challenge of dairy cows. J. Dairy Sci. 97:7426-7436.

Tienken, R., S. Kersten, J. Frahm, U. Meyer, L. Locher, J. Rehage, K. Huber, A. Kenez, H. Sauerwein, M. Mielenz, and S. Danicke. 2015. Effects of an energy-dense diet and nicotinic acid supplementation on production and metabolic variables of primiparous or multiparous cows in periparturient period. Arch. Anim. Nutr. 69:319-339.

van der Drift, S. G., M. Houweling, M. Bouman, A. P. Koets, A. G. Tielens, M. Nielen, and R. Jorritsma. 2015. Effects of a single glucocorticoid injection on propylene glycol-treated cows with clinical ketosis. Vet. J. 204:144-149.

van Knegsel, A. T., H. van den Brand, J. Dijkstra, W. M. van Straalen, R. Jorritsma, S. Tamminga, and B. Kemp. 2007. Effect of glucogenic vs. lipogenic diets on energy balance, blood metabolites, and reproduction in primiparous and multiparous dairy cows in early lactation. J. Dairy Sci. 90:3397-3409.

Van Saun, R. J., and C. J. Sniffen. 2014. Transition cow nutrition and feeding management for disease prevention. Vet. Clin. North Am. Food Anim. Pract. 30:689-719.

Vernon, R. G. 2002. Nutrient partitioning, lipid metabolism and relevant imbalances. Pages 210-223 in Recent Developments and Perspectives in Bovine Medicine. M. Kaske, H. Scholz, and M. Höltershinken, ed. Klinik für Rinderkrankheiten, Hanover, Germany.

Vernon, R. G., and C. M. Pond. 1997. Adaptations of maternal adipose tissue to lactation. J. Mammary Gland Biol. Neoplasia 2:231-241.

Vincent, J. B. 2000. The biochemistry of chromium. J. Nutr. 130:715718.

Vincent, J. B. 2004. Recent advances in the nutritional biochemistry of trivalent chromium. Proc. Nutr. Soc. 63:41-47.

Weber, C., C. Hametner, A. Tuchscherer, B. Losand, E. Kanitz, W. Otten, S. P. Singh, R. M. Bruckmaier, F. Becker, W. Kanitz, and H. M. Hammon. 2013. Variation in fat mobilization during early lactation differently affects feed intake, body condition, and lipid and glucose metabolism in high-yielding dairy cows. J. Dairy Sci. $96: 165-180$.

Williams, C., B. Crochet, L. Bunting, J. Fernandez, and C. Stanley. 2004. Metabolic responses of periparturient Holstein cows and 
heifers supplemented with chromium picolinate. Prof. Anim. Sci. $20: 312-318$.

Winkelman, L. A., and T. R. Overton. 2013. Long-acting insulins alter milk composition and metabolism of lactating dairy cows. J. Dairy Sci. 96:7565-7577.

Wisse, B. E. 2004. The inflammatory syndrome: The role of adipose tissue cytokines in metabolic disorders linked to obesity. J. Am. Soc. Nephrol. 15:2792-2800.

Yasui, T., J. A. A. McArt, C. M. Ryan, R. O. Gilbert, D. V. Nydam, F. Valdez, K. E. Griswold, and T. R. Overton. 2014. Effects of chromium propionate supplementation during the periparturient period and early lactation on metabolism, performance, and cytological endometritis in dairy cows. J. Dairy Sci. 97:6400-6410.

Yasui, T., M. M. McCarthy, C. M. Ryan, R. O. Gilbert, M. J. B. Felippe, G. D. Mechor, and T. R. Overton. 2016. Effects of monensin and starch level in early lactation diets on indices of immune function in dairy cows. J. Dairy Sci. 99:1351-1363.
Yuan, K., R. D. Shaver, S. J. Bertics, M. Espineira, and R. R. Grummer. 2012. Effect of rumen-protected niacin on lipid metabolism, oxidative stress, and performance of transition dairy cows. J. Dairy Sci. 95:2673-2679.

Zachut, M. 2015. Defining the adipose tissue proteome of dairy cows to reveal biomarkers related to peripartum insulin resistance and metabolic status. J. Proteome Res. 14:2863-2871.

Zachut, M., H. Honig, S. Striem, Y. Zick, S. Boura-Halfon, and U. Moallem. 2013. Periparturient dairy cows do not exhibit hepatic insulin resistance, yet adipose-specific insulin resistance occurs in cows prone to high weight loss. J. Dairy Sci. 96:5656-5669.

Zachut, M., and U. Moallem. 2017. Consistent magnitude of postpartum body weight loss within cows across lactations and the relation to reproductive performance. J. Dairy Sci. 100:3143-3154.

Zechner, R., P. C. Kienesberger, G. Haemmerle, R. Zimmermann, and A. Lass. 2009. Adipose triglyceride lipase and the lipolytic catabolism of cellular fat stores. J. Lipid Res. 50:3-21. 